\title{
The Mutuality of Challenges Facing Human Rights and Human Security: A New Framework of Analysis
}

\author{
Emmanuel Ome, Ani Casimir \\ Department of Philosophy, University of Nigeria, Nsukka, Nigeria \\ Email: dromemma@yahoo.com, cepperngo@gmail.com
}

Received 14 January 2015; accepted 3 February 2015; published 5 February 2015

Copyright (C) 2015 by authors and Scientific Research Publishing Inc.

This work is licensed under the Creative Commons Attribution International License (CC BY). http://creativecommons.org/licenses/by/4.0/

\section{(c) (i) Open Access}

\begin{abstract}
The interrelationship between Human Rights and "related fields" such as Human Security, Development, Democracy and Good Governance was emphasised at the United Nations Millennium Summit, which resulted in a declaration that affirmed global commitments to the protection of the vulnerable, the alleviation of poverty, and the rectification of corrupt structures and processesparticularly in those countries in which there is a lack of "rule of law" and good governance. The world's leaders resolved to spare no effort to promote democracy and strengthen the rule of law, as well as respect for all internationally recognized human rights and fundamental freedoms, including the right to Human Security. This paper intends to analytically discuss Human Rights and Human Security with a focus on the interrelationship between human rights and concepts such as the right to development, conflict prevention, peace-making and peace-building, poverty reduction and good govcernance.
\end{abstract}

\section{Keywords}

Human Rights, Security, Peace, Democracy, Development

\section{Introduction}

In his address to world leaders at the General Assembly on 10 November 2001, United Nations Secretary-General Kofi Annan emphasized the strategic importance of human security and human rights to the fundamental objectives of the Organization (United Nations, 2002: p. 385). He stressed that the United Nations must always stand for the rule of law in international and domestic affairs: "The United Nations must place people at the centre of everything it does"- enabling them to meet their needs and realize their full potential. In presenting "four 
burning issues”, the Secretary General cited the eradication of extreme poverty, the struggle against HIV/AIDS, the prevention of deadly conflict, and tackling the root causes of political violence-issues that threaten human security around the world (United Nations, 2000: p. 305). He declared, "The common thread connecting all these issues is the need to respect fundamental human rights” (Alston, 1999: p. 62). The challenges facing the international community at the present time are such that, without respect for human rights and fundamental freedoms, the attainment of lasting peace would be impossible and human security would remain illusory. This essay explores the relationship between human rights and human security and then turns to the challenges currently facing the United Nations - challenges that cannot be met without the central involvement of human rights approaches and strategies.

\section{Security Requires the Protection of Human Rights}

The Charter of the United Nations was signed on 26 June 1945 in San Francisco at the conclusion of the United Nations Conference on International Organization, and came into force on 24 October 1945 (Alston, 2002: p. 64). However, the idea of human rights did not begin with the establishment of the United Nations-its roots can be found in different world cultures and religions. The adoption of the Universal Declaration of Human Rights by the UN General Assembly in 1948 was a landmark achievement in world history as it was the first time that the international community set down formal standards of human rights and freedoms that should be enjoyed by everyone, everywhere. The Universal Declaration proclaims that respect for human rights is the foundation of freedom, justice and peace in the world (Buchanan, 2010: p. 33). The vision outlined in the Charter of the United Nations and in the Universal Declaration of Human Rights is that everything we do in the governance of human affairs must have in view the promotion and protection of basic human rights. It was a major breakthrough of the Universal Declaration of Human Rights to provide basic guarantees regarding food, health, education, housing, protection of the family, democracy, participation, the rule of law, and protection against enslavement, torture, cruel or inhuman or degrading treatment or punishment. These seminal provisions were amplified in subsequent human rights conventions and they have a simple rationale: human rights and fundamental freedoms must be respected, assured and protected if the individual human being is to be secure, to develop to the fullness of his or her potential and to breathe the air of liberty.

Security is a condition or feeling of safety, of being protected. International human rights norms define the meaning of human security. The Universal Declaration of Human Rights and the wider body of human rights instruments are all meant to make human beings secure in freedom, in dignity, with equality, through the protection of their basic human rights. Article 28 of the Universal Declaration of Human Rights is of crucial importance from this point of view. It provides that everyone is entitled to a social and international order in which the rights recognized in the Declaration can be realized.

The linkages between individual, national and international security can be stated quite simply. Individual security must be the basis for national security, and national security grounded in individual security must be the basis of international security. National security and international security cannot be achieved without respect for individual security in the form of respect for human rights and fundamental freedoms. In the contemporary world, there are many situations where oppression leads to gross violations of human rights, occasioning conflicts, occasioning displacement, occasioning the movements of refugees and migrants, and occasioning human suffering on massive scales (Cranston, 1973: p. 12). So many societies are raven with strife and poverty because democracy, the rule of law and respect for human rights are illusory. It is important to be clear about the strategic importance of respect for human rights in estab- lishment and maintenance of peace and security. In the first place, conflicts cannot be prevented or peace maintained in a world of wanton violations of human rights. In the second place, development strategies that have as their key objectives the realization of core economic, social and cultural rights and civil and political rights have the best prospect of leading to tangible improvements in the lives of human beings: people-oriented development and human security. In the third place, respect for human rights is the requirement for efficiency and effectiveness in governance (Amartya Sen, 2000). One is all too familiar with societies which, in the past half-century of international cooperation, have squandered vast amounts of resources and aid basically because the government was unrepresentative and, as a direct consequence, inefficient and often corrupt. Put simply, development is illusory without freedom (Brems, 2009: pp. 343-372). 
In the fourth place, the principle of non-discrimination, a bedrock principle of international human rights law, enables one to strive for more equitable societies even within the level of resources available.

\section{The Responsibilities of the International Community, Governments and Civil Society}

The core concept of the United Nations when the Charter was drafted was that the Security Council would act for the maintenance of international peace and security. Alongside this, the Organization would promote development and the universal realization of human rights. Peace, justice, respect for human rights, and economic and social progress in an interlocking relationship was, and remains, the vision of the United Nations (Pogge, 2002: p. 21).

Alas, it is a vision under challenge in a world of power disequilibria, of uneven quality of governance, of economic and social disparities, of contending value systems, and of shocking violations of human rights. The protection of human rights is at the heart of the Charter's strategy of a world of peace grounded in the rule of law and economic and social progress. If we are to vindicate and achieve the vision of the Charter, policies and strategies of Human rights and human security governance must be rooted in respect for human rights. Without protection of human rights the Charter's vision cannot be achieved. Without human rights, there can be no real and durable human security. The protection of human rights is at the heart of the Charter's strategy of a world of peace grounded in the rule of law and economic and social progress.

Without human rights the United Nations cannot accomplish its mission. It cannot be forgotten that the United Nations is comprised of individual Member States. Governments-working at the national, regional and international levels-must help realize the rights and freedoms that are contained in the international human rights conventions. In those instruments, they have defined what they consider to be the elements of human security. Governments should therefore be asking how they can devise policies and methods of governance that can help realize the specific rights and freedoms in the main human rights conventions (Claude \& Weston, 1992: p. 45).

In essence, this requires human rights strategies of governance: a conscious decision by governments and subjects that the aim of governance is to advance achievement of the key human rights—civil and political, economic, social and cultural.

The United Nations is founded upon the principle of government through consent of the governed. However, there is sometimes a gap between "the peoples" as envisioned in the UN Charter and their respective states. Not all states are responsive and responsible to their constituencies. It is for this reason that the United Nations places much value on its relations with civil society and that it is one of the cornerstones for its action in the future. The Secretary-General has recently established a panel on relations with civil society (Claude \& Weston, 1992). It will be important to draw insights from this experience into ways of strengthening the relationship between the United Nations and its base in the peoples of the world.

\section{Human Rights and the Global Challenges Facing the United Nations}

While much has been achieved in the first half century of the United Nations, one should not underestimate the enormity of the challenge that remains ahead. The difficulties of advancing human security through human rights in a world of tyrants, rampant poverty, conflicts, displacements, refugee outflows, and trafficking in human beings should not be underestimated. Some of the challenges confronting the United Nations in its efforts to bring about peace and security are considered below.

\subsection{Poverty and Development-Link to Human Rights}

1) In the Millennium Declaration, world leaders committed themselves to “... spare no effort to free our fellow men, women and children from the abject and dehumanizing conditions of extreme poverty, to which more than a billion of them are currently subjected. We are committed to making the right to development a reality for everyone and to freeing the entire human race from want” (United Nations, 2000: p. 305).

In addition; they resolved to "create an environment—at the national and global levels alike—which is conducive to development and to the elimination of poverty” (United Nations, 2000). Respect for human rights is criti- 
cal for a successful development strategy. The United Nations Development Programme’s 2000 Human Development Report forcefully argued that development strategies have to be anchored in human rights reasoning and have to be influenced in their conception and implementation by international human rights norms (United Nations, 2000). The rationales behind a human rights-based approach to development are many, but much of the impetus for it springs from the Secretary-General's reform programme of 1997, which called for the "mainstreaming" of human rights within the substantive areas of the UN's work (Amartya, 2000). The difficulties of advancing human security through human rights in a world of tyrants, rampant poverty, conflicts, displacements, refugee outflows, and trafficking in human beings should not be underestimated. This necessarily entails a conceptual framework for the process of human development that is normatively based on international human rights standards and operationally directed to promoting and protecting human rights. The objectives of a human rights-based approach are to address the discrimination, powerlessness and weaknesses in systems of accountability that lie at the root of poverty and other development problems by applying the standards and related principles and values of human rights throughout development policies, activities and programming cycles (United Nations, 2002). Additionally, the linkages between development and freedom are well-known (Barry Buzan/ Harvester, 1991: p. 43).

One can point to situation after situation in different parts of the world where the lack of freedom saps the creative capacity of the people and impoverishes them. Where people are free, they are inspired to create and to produce. They can be more efficient as they draw upon individual and corporate enterprise and explore new ways of doing things. Controlled economies are well-known to be inefficient economies. Where there is oppression and corruption, development can hardly take place. The centrality of human rights strategies of governance is therefore of the utmost importance. Those who live in poverty strive for dignity as much as anyone else and their voice must be acknowledged and listened to. The Universal Declaration of Human Rights provides a guideline for collective action towards the eradication of poverty ((Barry Buzan/Harvester, 1991: p. 43). The accomplishment of this goal requires good governance, democracy, the rule of law, non-discrimination, and constant attention to the implementation of basic human rights. It also calls for continued efforts, both by the UN and within each society, to identify the needs of the poor and the vulnerable and to respond to those needs tangibly. The Organization needs to be a moral voice drawing attention to the plight of the poor and promoting policies and strategies that can help relieve that plight.

\subsection{New Security Challenges: Terrorism}

Our future consideration of security challenges must recognize that what is perceived to be the nature of a threat for states has changed. The state-centered, geo-strategic political prism has been complemented by global, socioecological, developmental and cultural perspectives. This has led to a new category of challenges and conflicts that stem from an ideological and ethnic base (Barry Buzan/Harvester, 1991: p. 37). One of the most crucial challenges facing the international community today is assuring respect for human rights in the context of the struggle to defeat terrorism. The UN remains convinced that tolerance and respect among peoples, the foundation tenets of the Charter of the United Nations, are the most essential components of any security strategy for the future. The crux of our position is that terrorism must be fought within the prescribed boundaries of the international legal system and within the principle of proportionality. The United Nations has undertaken many important initiatives in the struggle to defeat terrorism, one of the principal ones being the establishment, at the behest of the Secretary-General, of the Policy Working Group on the United Nations and Terrorism, in October 2001. The Group's report, issued in 2002, identifies the policy dimensions of terrorism for the United Nations, and offers a series of thirty-one specific recommendations on steps the Organization can take to further address the problem and on how the UN system might function more coherently and effectively in this respect. In short, it aims to provide a strategic conceptual framework for future efforts.

The Working Group has focused on practical actions that the UN might perform in the following areas of activity and its recommendations fall into the same three categories: activities to dissuade disaffected groups from embracing terrorism (twelve recommendations), activities to deny groups and individuals the means to carry out terrorist acts (twelve recommendation), and efforts to sustain broad-based international cooperation in the struggle against terrorism (seven recommendations). Terrorism must be fought within the prescribed boundaries of the international legal system and within the principle of proportionality.

The urgent need for the UN human rights mechanisms to pay priority attention to the subject of the protection 
of human rights while countering terrorism is also clear. As a result, the Office of the High Commissioner for Human Rights (OHCHR) has supported the treaty bodies and mechanisms in addressing this issue more actively in their work by specifically including counter-terrorism measures on the list of issues taken up regularly with countries reporting to the Human Rights Committee (United Nations, 2002: p. 234). (Although a practical dilemma in this respect is that the Committee can only examine some forty country reports per year). In addition, OHCHR supports the Special Procedures in their interventions on this issue. Another initiative taken by the UN in response to the struggle against terrorism has been the appointment of Ms Kalliopi Koufa as the Special Rapporteur on Terrorism and Human Rights in 1998. Ensuring respect for human rights while struggling against terrorism is essential as it is only through the protection and promotion of human rights under the rule of law that terrorism can be prevented. The UN must project a clear and principled message that terrorism, whatever the cause in whose name it is undertaken, is unacceptable and deserves universal condemnation but that basic human rights standards must be respected in the fight against it. What will be the role of the United Nations in dealing with the security challenges of the future?

One of the major contributions of the United Nations Security Council since the end of the Cold War has been to consider security challenges in their classical context of war and peace issues as well as non-military threats (Henkin, Neuman, \& Orentlicher, 2001: p. 76). Today, issues such as HIV/AIDS, gross violations of human rights and terrorism are seen to fall within the Security Council's charge as it strives for the maintenance of international peace and security. Recent emphasis in the international community on human security has supported this trend by framing the diverse threats faced by humankind as questions of security.

\subsection{Conflict Prevention}

Leaving aside the debate over the proposition that democracies usually do not wage war on one another, one can point to many situations in today's world where different ethnic groups or different parts of a population have ended up in conflict because the ground rules in the society do not provide them with decent or equitable life chances or where one group within a society feels that it is the victim of unfair treatment (Durham, 2004: p. 21). A society that is striving in good faith for human rights, that is imbued with the spirit of respect for human rights, that is aspiring for a culture of human rights, is one that can lessen the risks of conflict. Strategies of conflict prevention must therefore be built integrally upon strategies of promoting and protecting human rights. The best conflict prevention strategy, at the end of the day, is a strategy of respecting human rights.

As conflict prevention is central to the future of the United Nations, one might ask what the United Nations should be doing to promote it. A lot is already happening in this regard within the Organization. For example, the Department of Political Affairs has a Framework Team to help identify situations of concern. The Secretary-General's contacts with members of the Security Council and Secretariat briefings to the Council in informal consultations are important contributions to conflict prevention. Cooperation between the United Nations and regional organizations for conflict prevention has also been developing. A society that is striving in good faith for human rights, that is imbued with the spirit of respect for human rights, that is aspiring for a culture of human rights, is one that can lessen the risks of conflict.

More could be done within the Organization to promote conflict-prevention strategies based in human rights. The Secretary-General could brief the Security Council informally once a fortnight or once a month on situations giving rise to concern. The Security Council might consider a system of regional rapporteurs who could present situations of concern to it, drawing upon information gathered by the Secretariat or provided by Member States and NGOs (Durham, 2004: p. 21). A regular briefing to the Security Council from the Chairman of the Commission on Human Rights would be one way of ensuring that human rights inputs are injected into conflict prevention efforts. In addition, OHCHR briefs the incoming President of the Security Council on a monthly basis, on human rights-related issues. This indicates a growing acceptance on the part of the Security Council that human rights issues fall within the purview of its work.

\subsection{Peace-Making}

The incorporation of human rights in peace-making has been the subject of much discussion, and one should be 
careful about laying down too many strictures upon a peace-maker as each situation is unique. However, while not underestimating the complexity of the peace-making task, it would be a fair proposition to say that a peace that is not accompanied by strategies for the promotion and protection of human rights is unlikely to be a lasting one. Peace-making must be built on human rights foundations. In situations as diverse as in Nigeria, America, in Cambodia, in the former Yugoslavia and elsewhere, the peace-maker's package has included strategies to uphold human rights. One must build upon these experiences and try to provide practical human rights tools to peace-makers.

By its very nature and essence, the United Nations is a pre-eminent peace-maker. Some claim that the United Nations has drawbacks as a peace-maker, stemming largely from its lack of power. One cannot gainsay this. The fact remains, however, that it falls to the United Nations to do whatever it can to help promote peace regardless of the colour or stripe of the nations in conflict. What more can the United Nations do to develop its capacity and skills for peace-making? It is important to develop a pool of lessons learned from past peace-making experiences. The United Nations Staff College has developed some relevant training exercises for United Nations personnel. It might be useful to envisage an annual course or courses for serving, potential or past peace-makers. Human rights insights would be an invaluable part of such courses. International research institutes such as the International Peace Academy complement the role of the United Nations.

\subsection{Peace-Keeping and Peace-Building}

The peace that is put together by a peace-maker must be taken forward and safeguarded by peacekeepers and by peace-builders. Peace-keeping and peace-building would be devoid of meaning unless they incorporated a human rights component. This is why peace-keeping operations nowadays have human rights staff as standard components and peace-building packages have increasingly included human rights.

Historically, United Nations peace-keepers were interposed between warring nations when they were willing to agree to the presence of a neutral party. These days, however, most conflicts are internal in nature and the combatants often do not respect the laws and customs of war or of the neutrality of the United Nations. Where United Nations peace-keeping and building should be headed? Could it be that the time has come to concentrate on rapidly deployable contingents of United Nations observers to trouble spots where the deployment might serve to mitigate the excesses of conflict? The Organization appears to be moving along those lines as it distils the lessons learned from past peace-keeping experiences, identifies best practices and incorporates other vital aspects such as gender, disarmament and demobilization into the peace-keeping equation.

The August 2000 "Report of the Panel on United Nations Peace Operations" was the first comprehensive review of UN peace-keeping operations in the Organization's history. Drafted by a panel of experts headed by former Algerian Foreign Minister Lakhdar Brahimi, it recommends specific improvements in the way the UN Secretariat, Security Council and participating Member States conceive and implement peace and security activities. Such reforms are necessary, the panel argues, because peace-keeping missions are increasingly responding to "complex" conflicts within states rather than "traditional” conflicts between states. The consent of local parties, impartiality and use of force only in self-defence should remain core principles. Where one or more parties are an "obvious aggressor", however, peace-keeping troops must not "cede the initiative to their attacker. ... Impartiality must mean adherence to the principles of the UN Charter, not equal treatment of all parties at all times” (Katayanagi in Kluwer, 2002: p. 33). Where local actors' intentions are suspect, peace-keeping missions must be larger and better equipped to act as credible deterrents with "robust" rules of engagement. Since the concept of peace-building was first introduced in 1992, the United Nations has had peace-building offices in Liberia, Central African Republic, Burundi, Burma, Great Lakes Region, Guatemala, Guinea-Bissau, the Middle East, Somalia and Tajikistan. There are currently twelve ongoing missions of a peace-building nature (Afghanistan, Bougainville, Burundi, Central African Republic, Guatemala, Great Lakes Region, Guinea-Bissau, Occupied Territories, Somalia, Tajikistan, West Africa and Côte d'Ivoire (Gewirth, 1982: p. 77).

The United Nations peace-building offices can be instrumental in supporting and closely collaborating with the country teams and non-resident United Nations agencies/offices, as well as in developing multifaceted programmes that address many of the root causes of conflict. These offices work closely with government ministries, national assemblies, political parties, civil society and other local actors to support national peace-building efforts. It should be kept in mind that a real and lasting peace among nations cannot be es- 
tablished solely on the basis of a balance of political forces and interests and on an equal supply of armaments (United Nations, 2000: p. 305). This is merely the absence of war. True peace can only be founded on mutual trust achieved through the inculcation of the basic values upon which the Universal Declaration and the UN Charter are founded.

\subsection{Humanitarian Strategies}

In the negotiations that led up to the establishment of a position of United Nations Emergency Relief Coordinator within the Office for the Coordination of Humanitarian Affairs, the General Assembly laid down some principles to guide the United Nations in the humanitarian sphere. These included, among others that humanitarian assistance must be provided in accordance with the principles of humanity, neutrality and impartiality. In addition, the sovereignty, territorial integrity and national unity of states must be fully respected in accordance with the Charter of the United Nations. In this context, humanitarian assistance should be provided with the consent of the affected country and, in principle, on the basis of an appeal by the country. Each state has the responsibility first and foremost to take care of the victims of natural disasters and other emergencies occurring on its territory. Hence, the affected state has the primary role in the initiation, organization, coordination and implementation of humanitarian assistance within its territory.

The United Nations has a central and unique role to play in providing leadership and coordinating the efforts of the international community to support the affected countries and should ensure the prompt and smooth delivery of relief assistance in full respect of the above-mentioned principles. Some of the central challenges facing the United Nations in the humanitarian area have been the debate on the "right of humanitarian intervention" tied to the problem of access and the increasingly common and deliberate targeting of humanitarian workers. The former is now generally viewed as more of a "responsibility to protect" rather than a "right to intervene" while the latter continues to be of the gravest concern for United Nations action in the humanitarian sphere (United Nations, 2000: p. 305).

\section{Human Rights Protection at the National Level-Exploring Mutual Challenges}

Democracy, the rule of law and respect for human rights are important not only as intrinsic values but also because they are crucial for the prevention of conflicts and for the alleviation of poverty. In his report "Strengthening of the United Nations”, Secretary-General Kofi Annan called upon the organizations and agencies of the United Nations system to concert their efforts to respond to requests from Member States for assistance in the strengthening of their national human rights protection systems (United Nations, 2000: p. 304). This will be one of the central challenges of the United Nations in the coming period. As the Secretary-General stressed, building strong human rights institutions at the national level is what will ensure that human rights are protected and advanced in a sustained manner in the long run. The emplacement or enhancement of a national protection system in each country, reflecting international human rights norms, should therefore be a principal objective of the Organization. These activities are especially important in countries emerging from conflict. OHCHR is giving priority to the establishment and strengthening of national human rights institutions in accordance with the relevant international standards. It continues to provide practical advice to the growing number of countries requesting it, works for the improvement of United Nations system-wide coordination in the work of national institutions, and supports an increased participation of national institutions in appropriate United Nations human rights and other international for a (United Nations, 2000: p. 304). OHCHR encourages the sharing of best practices among national institutions and facilitates their access to relevant information. It also supports the strengthening of regional networks of national institutions.

\section{Challenges of Mindsets-Link between the Individual, National and Global Security}

One of the major challenges that humanity faces is that of mindsets. Mindsets include the way people think about one another, the principles of tolerance and respect, the issue of cultural diversity, and consumption patterns in the North. It will be important to rally the peoples of the world behind global values rooted in the Universal Declaration of Human Rights. As these values are based on the fundamental dignity inherent in the human condition, we profess the freedom, equality and unity of all peoples. We must continue to do our utmost to promote these values and to change the attitudes and mindsets that are contrary to them. In this respect, education-particularly of the young—is crucial. 
Education is meant to lead to liberation and peace, to share the knowledge and insights that each individual possesses and to bring a person to a greater awareness of personal dignity. In short, education should aim to instil an appreciation of the dignity of every person irrespective of race, creed or colour, communicate the interconnectedness of all and teach how to accept one's past, be committed to the future and thus live at peace in the present (United Nations, 2000: p. 305).

\section{Conclusion}

The attainment of human security is contingent upon respect for human rights, which is at the centre of all United Nations activities. It is my profound conviction that the United Nations can only fulfil its mission by giving a central place to human rights (Hayden, 2002: p. 49).

The Secretary-General has stated his determination to integrate human rights even more fully into every aspect of the work of the Organization. It is my hope that we can achieve a secure world through confronting the challenges of the future in as courageous and ethical a manner as possible and by maintaining the human being as the reference point for all UN policies.

\section{References}

Alston, P. (1999). Promoting Human Rights through Bills of Rights. Oxford: Oxford University Press, 62.

Alston, P., \& Crawford, J. (2002). The Future of UN Human Rights Treaty Monitoring. Cambridge: Cambridge University Press, 43.

Brems, E. (2009). Human Rights: Minimum and Maximum Perspectives. Human Rights Law Review.

Buchanan, A. (2010). Human Rights, Legitimacy, and the Use of Force. Oxford: Oxford University Press.

Cranston, M. (1973). What Are Human Rights? London: Bodley Head.

Durham, H. (2004). We the People: The Position of NGOs in Gathering Evidence and Giving Witness in International Criminal Trials. In R. Thakur, \& P. Malcontent (Eds.), From Sovereign Impunity to International Accountability. New York: United Nations University Press.

Gewirth, A. (1982). Human Rights. Chicago: University of Chicago Press.

Hayden, P. (2002). The Philosophy of Human Rights. St. Paul, MN: Paragon Press.

Henkin, N. et al. (2001). Human Rights. New York: Foundation Press.

Katayanagi (2002). Human Rights Functions of United Nations Peacekeeping Operations. The Hague: Kluwer.

Pogge (2002). World Poverty and Human Rights: Cosmopolitan Responsibilities and Reforms. Cambridge: Polity Press.

Sen, A. (2000). Development as Freedom. Anchor.

United Nations (2000). Report of the Panel on United Nations Peace Operations. United Nations Document A/55/305.

United Nations (2002). Strengthening of the United Nations: An Agenda for Further Change. United Nations Document A/57/387. 
Scientific Research Publishing (SCIRP) is one of the largest Open Access journal publishers. It is currently publishing more than 200 open access, online, peer-reviewed journals covering a wide range of academic disciplines. SCIRP serves the worldwide academic communities and contributes to the progress and application of science with its publication.

Other selected journals from SCIRP are listed as below. Submit your manuscript to us via either submit@scirp.org or Online Submission Portal.
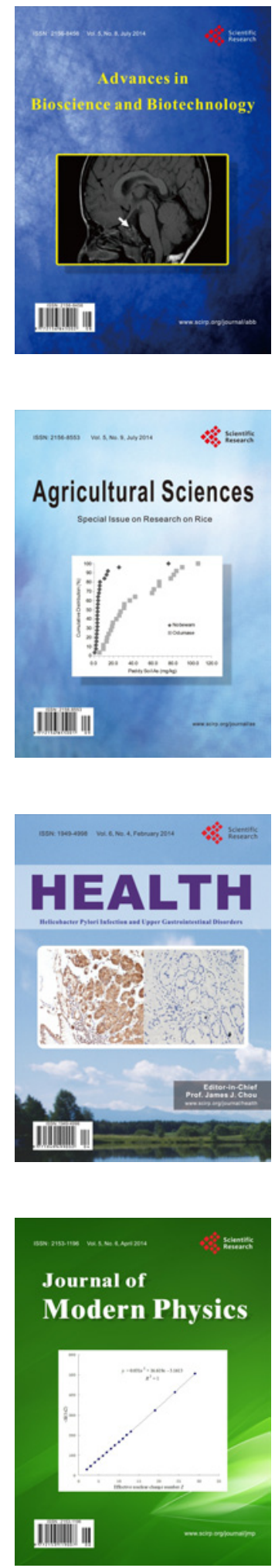
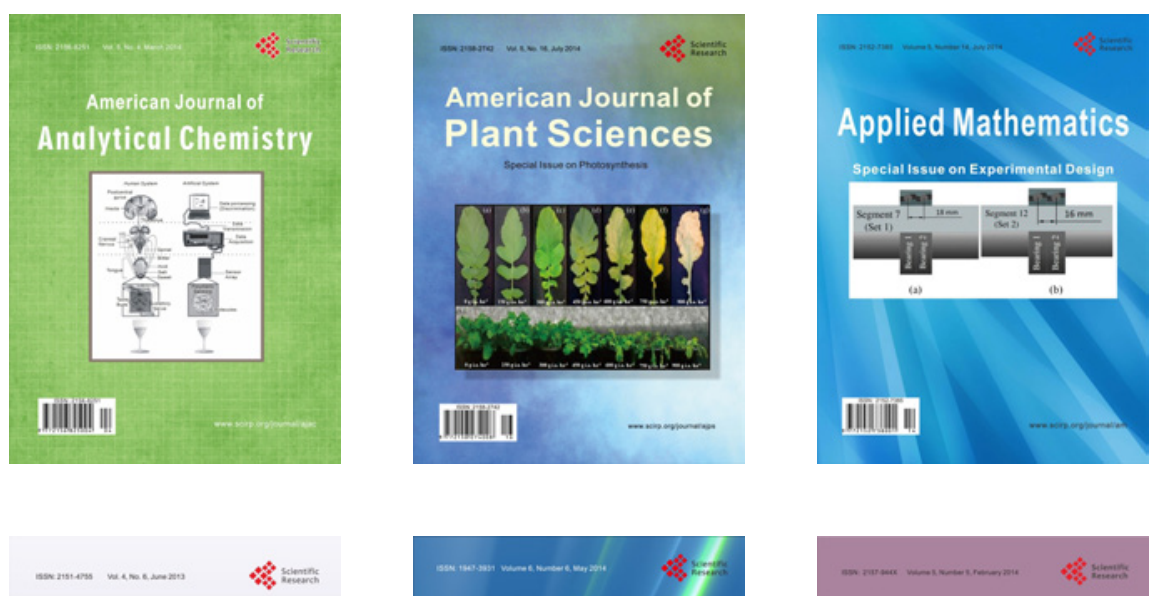

Creative Education
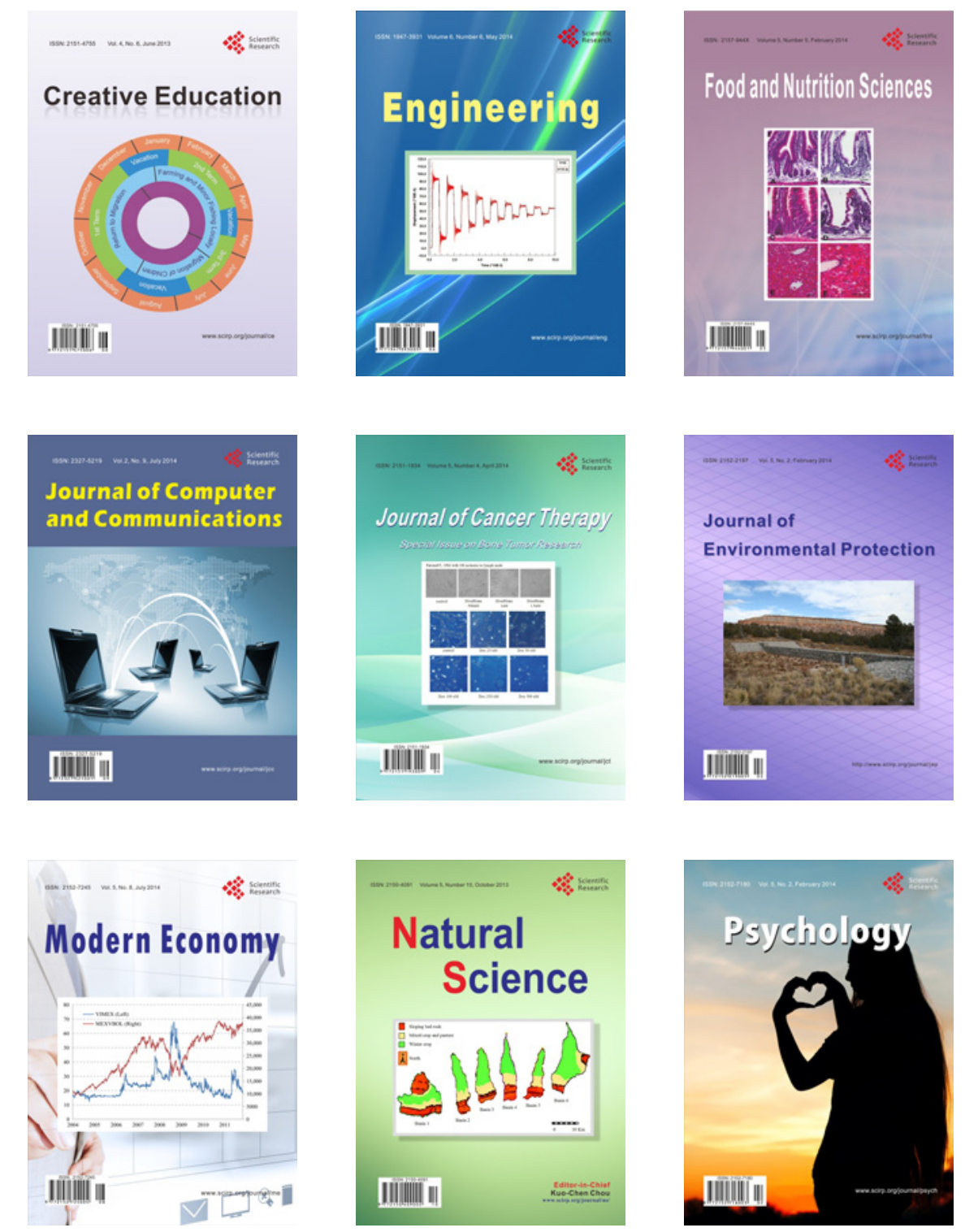